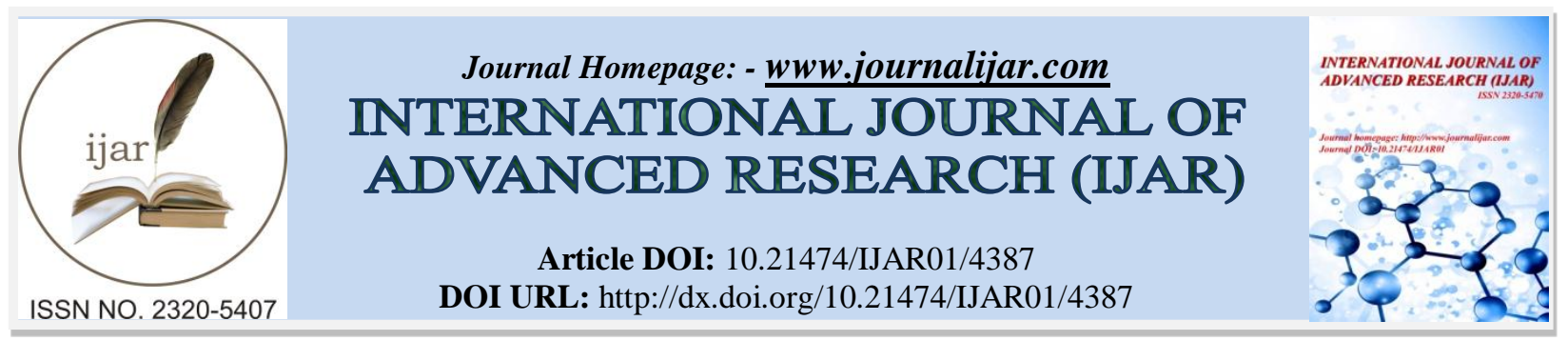

RESEARCH ARTICLE

\title{
EFFECT OF ORGANIZATIONAL COMMITMENT ON PERFORMANCE STUDY IN DISTANCE EDUCATION UNITS OF UNIVERSITAS TERBUKA OF CENTRAL JAVA.
}

Sri Sumiyati.

Economics Education Program, Fakultas Keguruan dan Ilmu Pendidikan. Unit Program Belajar Jarak JauhUniversitas Terbuka (UPBJJ-UT) Semarang, Jl. Semarang-Kendal KM 14,5. Mangkang Wetan.

Semarang. Indonesia.

\section{Manuscript Info}

Manuscript History

Received: 03 april 2017

Final Accepted: 05 june 2017

Published: june 2017

Key words:-

affective commitment, normative commitment, continuance commitment, performance

\section{Abstract}

Purpose of the study is to examine effect of organizational commitment on performance of employees in Distance Education Units (DEUs) of Universitas Terbuka (UT) of Central Java. The research is a hypothesis testing one with a causal model examining relationship of variables with each other. The study used individuals working in The Universitas Terbuka of Central Java region as unit of analysis. Sample of study was part of the employee population taken as data source and they can represent the entire population. The sample was taken by means of census and all employees of DEUs of Central Java amounting to 156 employees were used as research sample (census). Results of the study provided evidence that affective commitment of employees had an insignificant positive effect on performance. The results also showed that normative commitment and continuance commitment of employees to make a change had a significant positive effect on performance.

Copy Right, IJAR, 2017,. All rights reserved.

\section{Background of the Research:-}

According to Robbins (2003), an organization can be perceived through behavior of members or employees of the organization itself, namely by considering their ways of thinking, feeling, responding and guiding members of the organization in making decisions and other activities within the organization. Characteristics of an individual are traits or characters of each individual that will affect behavior of the individual in an organizational activity. These individual characteristics are strongly influenced by internal factors of an organization. In this case, task of the organization is to organize and to seek the way to make the characteristics can always lead to achievement of predefined organizational goals.

Behaviors and attitudes of employees in their works will affect quality of the works produced. Furthermore, behaviors and attitudes of the employees will reflect their commitments to organization. Good working commitment of employees in an organization will also reflect good performance because the more loyal the employees to job, any work assigned to them will be done passionately. 
The commitment according to Mowday, Steers and Porter (in Luthans, 2006) is defined as the degree of relative attachment of an individual to the interests of organization and the degree of his/her involvement characterized by three factors:

1. a strong will to belong to an organization,

2. an availability to make their best for the goodness of organization, and

3. a strong trust and acceptance of organizational values and goals.

Research by Hesket (1998) stated more specifically that employees' commitment in organization has two different levels if viewed from aspects of clarity and organizational resilience to change. At an inner level, the organizational commitment refers to shared values shared by people in one group and it tends to persist when members and groups even change. This understanding covers what is important in life and it can vary across organizations. For example, in some cases people are very concerned about money, technological innovation or member welfare. At a more visible level, culture reflects pattern or behavioral style of an organization so that new members are automatically encouraged to follow behavior of their co-workers.

Research by Parish, Cadwallader and Busch (2008) on employee commitment described role of employee commitment for a successful organizational attempt in making changes. The research aimed to analyze suitability of organizational change with organizational vision influencing affective, normative and continuance commitments of employees to make a change, also whether leader relationship with subordinates affects affective, normative and continuance commitment of the employees to make a change, also whether working motivation affects affective, normative and continuance commitments of employees to make a change, and whether role autonomy influence the affective, normative and continuous commitment of the employees to make a change. In addition, the study also sought to analyze effect of affective and normative commitments of employees on their performance.

Purpose of the present study is to examine effect of organizational commitment on performance of employees in Distance Education Units (DEUs) of the Universitas Terbuka (Indonesian Open University) of Central Java region. Universitas Terbuka (UT) is a university institution serving to preserve, develop, disseminate and explore science, technology and to expand learning opportunities in higher education for people through Open and Distance Education System (ODES), thus producing graduates with academic and/or professional competencies who are capable to compete globally.

\section{Theoretical Basis:- \\ Organizational Commitment:-}

Randall (in Alwi, 2008) defines that commitment to organization is a relative strength of individual identification with involvement in organization. Three components of organizational commitment are:

1. belief in- and accept organizational goals,

2. availability to be a part of the organization, and

3. a will to maintain membership in the organization.

Furthermore, commitment can be described as a continuum moving from a low, moderate, and high level with positive and negative influences. In low commitment, negative impacts on an individual can span from a slow career advancement and promotion, to the worst, expelled from organization or make efforts to hinder goals of the organization. At organizational level, the low commitment of members to an organization can impact on increased level of quitting workers and absenteeism, poor quality of work, low loyalty and frequent activities against the organization.

In high commitment can produce negative impacts on individuals, among others: eliminates power of creativity, innovation, and opportunity to a new way of work, resistant to change, experiencing stress and pressure in family and social environment, lack of solidarity among colleagues, and limited time for things outside the work.

By considering consequences or positive impacts of low and high commitment on individuals and organizations, then for practitioner is to consider level of organizational needs for commitment by making an organizational change. To reduce level of commitment, Randall (in Alwi, 2008) provides a technique by providing assessment of individual behavior and reducing resistance of individuals to change. However, in the future, leaders are expected to be able to accommodate employees to accept the changes. 
According to Morgan and Hunt (2004), commitment indicates a will to keep a value. Thus, commitment of employee can be interpreted as a desire to keep value of employee for organization in work place. Commitment viewed from organizational behavior is a type of critical relationship commitment in an enterprise involving all employees in a company from the oldest to the youngest (Becker, in Morgan and Hunt, 1994). In this context, Morgan and Hunt (1994) concluded commitment can be seen as a center of everything delivering important results such as reduced employee turnovers, and improvement of employee behavior in organization, but it is also the result of everything influenced by a company when conducting employee recruitment and training, job fairness, and organizational support.

\section{Employee Performanc:-}

According to Mangkunegara (2004) performance is a result of work qualitatively and quantitatively achieved by an employee in performing his duties in accordance with assigned responsibility. While, Prawirosentoso (1999) argued that performance is a work achieved by a person or a group of persons in an organization in accordance with authority and responsibility of each in order to achieve relevant organizational objectives legally in accordance with moral and ethics.

Performance appraisal should be conducted in order to enable an effective management process. It is further explained that performance appraisal gains four benefits, namely: (1) to make decision about reward (bonuses, pay increases, and other forms of reward); (2) to make decision on career development (promotion, demotion, and job transfer); (3) to provide feedback to employees on their performances over a period of time; (4) to identify the needs of training and development.

On factors affecting performance, Anwar Prabu Mangkunegara (2004) suggests that the factors affecting achievement of performance are:

Factor of Competence:-

Competence of an employee is a combination of potential IQ ability and reality ability (knowledge + skill). Therefore, an employee should be put in a job suitable with his or her expertise (the right man in the right place, the right man on the right job).

\section{Factor of Motivation:-}

Motivation is formed by attitude of employee in facing work situations. Motivation will encourage workers to achieve goals of an organization they work in.

\section{Development of Hypotheses:-}

Research on employee commitment by Parish, Cadwallader and Busch (2008) described role of employee commitment in organizational success in making a change. This result showed a positive influence of affective commitment on performance, while normative commitment influenced performance insignificantly.

Research by Lehesvitra (2004) concluded that employee commitment has a positive effect on performance. Results of research by Parish, Cadwallader and Busch (2008) concluded that affective commitment had positive effect on performance and influence of normative commitment on performance was not significant.

Based on results above, hypotheses related to effect of employee commitment on performance can be described as follows:

Hypothesis 1: Affective commitment has a positive effect on performance.

Hypothesis 2: Normative commitment has a positive effect on performance.

Hypothesis 2: Continuous commitment has a positive effect on performance. 
Based on the theoretical basis and previous researches, a research framework can be illustrated as follows:

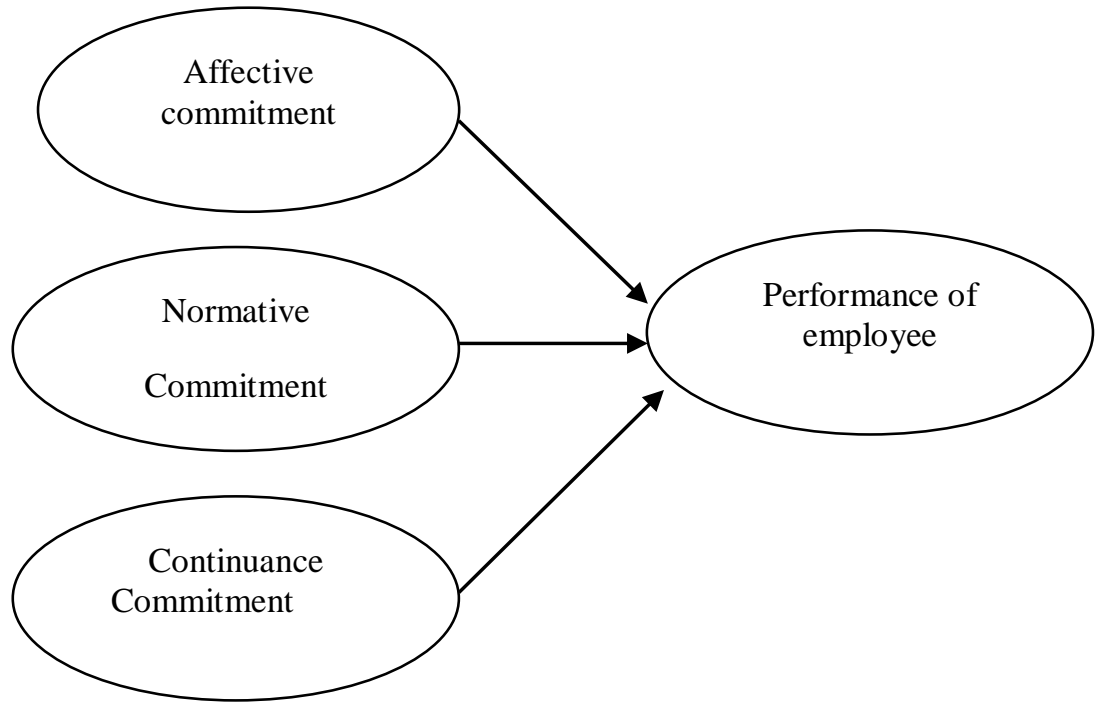

Figure 1:- Research Model.

\section{Methodology of Research:-}

\section{Research Design:-}

Jogiyanto (2005) suggested types of researches consisting of exploratory and hypothesis testing. The present research is a hypothesis testing one with causal model testing relationship of one variable to another

\section{Unit of Analysis:-}

Analysis unit may consist of individuals, group of multiple data pairs, groups and organizations (Jogiyanto, 2005). Unit of analysis of this study are employees of UT in the Central Java region.

\section{Sample:-}

Arikunto (2003) says that: sample is a part of population (partially or representative of the population under study). Sample of the study was part of the population that has been taken as a data source and they can represent the entire population. The sample was taken by using census technique, namely all employees of DEUs of UT in Central Java number amounting to 156 employees were used as research sample (census).

\section{Operational Definition of Variables:-}

Operational definitions of each variable can be explained as follows:

a. Affective commitment of employees to make a change

Affective commitment of the present study is a will of an individual to maintain membership in organization because of his or her own desire. Data of the affective commitment was obtained from questionnaire developed by Herscovitch and Meyer (2002) consisting of four items of questions with 4 points of likert scale measurement.

b. Continuance commitment of employees to make a change

Continuance commitment of the present study is an individual commitment based on consideration of an individual about what is the cost of leaving an organization. Data of the continuance commitment was obtained by using a questionnaire of Herscovitch and Meyer (2002) consisting of three items of questions with 4 points of likert scale measurement.

c. Normative commitment of employees to make a change.

Normative commitment of the present study is a belief held by an individual about responsibility to an organization, thus he or she decides to remain in the organization. Data of the normative commitment was obtained by using a questionnaire developed by Herscovitch and Meyer (2002) consisting of four items of questions with 4 points of a likert scale measurement.

d. Performance

Performance of the present study is a work achieved by employees in a specified period. Data of the performance was obtained by using a questionnaire of Homburg et al. (2002) consisting of four items of questions with 4 points of likert scale measurement. 


\section{Data Collection technique:-}

Data of the present study was primary data collected by conducting direct observation, questioner, and interview guide, thus the design was made as efficient as possible with tools and techniques and characteristics of the respondents (Nasir, 1999).

\section{Result of the Research:-}

Multiple Regression Model:-

Statistical test of regression analysis for hypotheses in this study can be seen in the table below.

\begin{tabular}{|c|c|c|c|c|c|c|}
\hline & 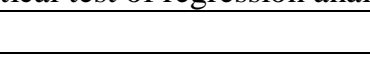 & Coeffic & nts $^{\mathrm{a}}$ & & & \\
\hline & & Unstandardized & efficients & Standardized & $\mathrm{t}$ & Sig. \\
\hline & & B & Std. Error & Beta & & \\
\hline 1 & (Constant) & -.160 & .702 & & -.228 & .820 \\
\hline & Affective commitment & .006 & .012 & .006 & .489 & .626 \\
\hline & Normative commitment & .533 & .042 & .530 & 12.667 & .000 \\
\hline & Continuance commitment & .467 & .041 & .471 & 11.254 & .000 \\
\hline & endent Variable: Perform & ployees & & & & \\
\hline
\end{tabular}

Based on results of the regression as listed in the table, a linear regression equation can be produced as follows:

Performance $=-0.160+0.006 \mathrm{KA}+0.533 \mathrm{KN}+0.467 \mathrm{KK}$

Based on multiple linear regression equation in the table above, it can be seen that:

a) Constant value of -0.160 with a negative sign indicates a non-directional relationship. It shows that if variables of affective commitment, normative commitment and continuance did not exist, performance of employees will decrease.

b) Regression coefficient value of affective commitment is 0.006 with a positive sign. It means a direct relationship exists between affective commitment and performance. Therefore, an increase of affective commitment will produce an increased performance.

c) Regression coefficient value of normative commitment is 0.533 with a positive sign indicating a unidirectional relationship between normative commitment and performance. It means that an increase of affective commitment will enhance performance.

d) Regression coefficient value of continuance commitment is 0.467 with a positive sign indicating a direct relationship between continuance commitment and performance. Thus, an increase of continuous commitment will improve performance.

\section{Results of Statistical F-Test:-}

Effects of independent variables on dependent variable can be tested collectively for their degree of significance by using F-test. Data and analysis process of the F-test are similar to multiple linear regression analysis, in other words, value of $\mathrm{F}_{\text {calculation }}$ and its significance are also produced when multiple regression analysis is conducted. Results of the F-test can be seen in table below.

Table 2:- Results of F-test

\begin{tabular}{|c|c|c|c|c|c|c|}
\hline \multicolumn{7}{|c|}{ ANOVA $^{b}$} \\
\hline \multicolumn{2}{|c|}{ Model } & Sum of Squares & $\mathrm{df}$ & Mean Square & $\mathrm{F}$ & Sig. \\
\hline \multirow[t]{3}{*}{1} & Regression & 957.796 & 3 & 319.265 & 1974.772 & $.000^{\mathrm{a}}$ \\
\hline & Residual & 21.017 & 130 & .162 & & \\
\hline & Total & 978.813 & 133 & & & \\
\hline \multicolumn{7}{|c|}{ a. Predictors: (Constant), continuance commitment, affective commitment, normative commitment } \\
\hline \multicolumn{4}{|c|}{ b. Dependent Variable: employee performance } & & & \\
\hline
\end{tabular}

Result of the F-test analysis obtained $F_{\text {calculation }}$ value of 1974.772, and $F$ table $(2 ; 143)$ of 3.00 with significance value of 0.000 . It means that $\mathrm{Ho}$ is rejected. It can be concluded that a significant effect of continuance commitment (CC), affective commitment (AC) and normative commitment (NC) simultaneously on performance (P) is found. 


\section{Results of t-test:-}

T-test analysis is used to test effect of each independent variable on dependent variable partially. Based on the results of data analysis, $\mathrm{t}$-values were obtained as follows:

Table 3:- Results of t-tes

\begin{tabular}{|l|l|l|l|l|}
\hline Variables & $\mathbf{T}_{\text {calculation }}$ & Significance & $\mathbf{t}_{\text {table }}$ & Conclusion \\
\hline Affective commitment & 0.489 & 0.626 & 1.960 & Rejected \\
Normative commitment & 12.667 & 0.000 & 1.960 & Accepted \\
Continuance commitment & 11.254 & 0.000 & 1.960 & Accepted \\
\hline
\end{tabular}

Source: Data processing, 2017

Values of $\mathrm{t}_{\text {calculation }}$ for affective commitment (AC), normative commitment (NC) and continuance commitment (CC) are greater than $t_{\text {table }}$ values, so Ho is accepted. Thus, it can be concluded normative commitment (NC) has a significant effect on performance and continuance commitment (CC) is also significantly affecting performance individually. While affective commitment (AC) is insignificantly affecting performance (P).

\section{Determination Coefficient Test:-}

Coefficient of determination is used to know magnitude of effect of independent variable on dependent variable. Based on results of regression test, the effect magnitude can be seen in the table below.

Table 4:- Results of Determination Coefficient Test.

\begin{tabular}{|c|c|c|c|c|}
\hline \multicolumn{5}{|c|}{ Model Summary } \\
\hline Model & R & R Square & Adjusted R Square & Std. Error of the Estimate \\
\hline 1 & $.989^{\text {a }}$ & .979 & .978 & .40208 \\
\hline \multicolumn{5}{|r|}{ a. Predictors: (Constant), continuance commitment, affective commitment, Normative commitment } \\
\hline
\end{tabular}

Based on results of the test, it can be seen that the adjusted $\mathrm{R}$ Square value is 0.978 , so it can be interpreted that affective commitment (AC), normative commitment (NC) and continuance commitment (CC) have effect of $97.8 \%$ on performance, while the rest of $2.2 \%$ are influenced by variables other than described in this model such as work motivation, wage, employee discipline, and so forth.

\section{Discussion:-}

Results of the hypothesis testing in the present study proved that affective commitment has no positive effect on performance. Also, it was showed that affective commitment of employees to make a change had insignificant positive effect on their performances. The present study does not support previous research conducted by Cadwallader and Busch (2008) concluding that employee commitment has a positive effect on performance.

Results of the present study proved the second and third hypotheses explaining that normative commitment and continuance commitment have a positive effect on performance. Furthermore, the results also indicated that normative commitment of employees to make a change had positively and significantly influenced their performances. Results of study by Parish, Cadwallader and Busch (2008) showing effect of normative commitment on performance are inversely related to this present study with no significant result in previous study.

\section{Conclusions and recommendations for future research:-}

Results of the study provide evidence that affective commitment of employees has an insignificant positive effect on performance. Also, the results showed that normative commitment and continuance commitment of employees to make a change have a significant positive effect on performance.

Future research should use method of pre-test questionnaire to avoid invalid questions in process of data analysis. Future research in this field should use in-depth interview in addition to questionnaire for data collection in order to obtain more complete data. 


\section{Reference:-}

1. Anwar Prabu Mangkunegara. 2004. Manajemen Sumber Daya Manusia Perusahaan. Bandung: Remaja Rosdakarya.

2. Baron, Greenberg. 1997. "Conceptualizing how job involvement and organizational commitment affect turnover and absenteeism”, Academy of Management Review, Vol. 12 No. 2, pp. 288-300.

3. Ferdinand, Agusty. 2002. An analysis Marketing Instrument in the competitive market, an applied study of the Japanese automobile industry, Journal of economic society, Vol. 06 No. 1, pp.321 - 334

4. Ghozali, Imam. 2005. Analisis Multivariate dengan menggunakan Program SPSS. Semarang: BP Undip.

5. Hesket J.L. Jones. 1998. Putting The Service Profit Chain to work. Harvad Business Review. Vol. 72. pp 164 174.

6. Homburg, C., Hoyer, W.D. and Fassnacht, M. (2002), “Service orientation of a retailer's business strategy: dimensions, antecedents, and performance outcomes", Journal of Marketing, Vol. 66, pp. 86-101.

7. La Mastro, Valeria. 2002. "Commitment And Perceived Organization Support. Rowan University., Journal of Workplace Learning, Vol. 16 Nos 1/2, pp. 92-100.

8. Luthans, F., 1995: Organizational Behavior, Seventh Edition, Singapore: Mc Graw - Hill.

9. Meyer, J.P., Becker, T.E. and Vandenberghe, C. 2004, "Employee commitment and motivation: a conceptual analysis and integrative model”, Journal of Applied Psychology, Vol. 89 No. 6, pp. 991-1007.

10. Morgan RM. and Hunt S.D. 1994. The Commitment - Trust Theory of Relationship Marketing. Journal of Human Resource. Volume 58. pp. 20 - 38.

11. Parish, Cadwallader and Busch. 2008. Want to, need to ought to :unemployed commitment to organizational change. Journal of Organizational Change Management. Vol. 21, pp. $32-52$.

12. Preffer J. 1994. Competitive Adventage thought People : Un Leashing the Power of the Workforce. Boston, M.A: Harvard Business School Press.

13. Robert and Hunt. 1991. Performance differences among four organizational commitment profiles", Journal of Applied Psychology, Vol. 90, pp. 1280-7.

14. Sekaran, Uma. 2000. Research Methods for Business: A skill Building Approach. Second Edition, New York: Jhon Wiley and Sons, Inc

15. Temaluru. 2001. Organizational Commitment in the Slovenian Police Force. US. Government Review. 